\title{
DOES ABSENCE MAKE THE HEART GROW FONDER? - STUDENTS' PERSPECTIVES OF CURRICULUM, ABSENTEEISM AND THEIR PURSUIT OF THE GOOD LIFE
}

\author{
Simon Edwards* and Evie Parmar**
}

\section{ABSTRACT}

In 2015, major revisions were made to the breadth and content of the English national curriculum to ensure the country's economic success in an emerging technological marketplace (Brynjolfsson and MacAfee; DfE 2016). ${ }^{1}$ Increasingly punitive sanctions were introduced to safeguard student attendance and subsequent attainment (Criminal Justice and Courts Act 2015; DfE 2017a). ${ }^{2}$ Yet student GCSE attainment has remained static since 2015 (DfE 2018a) ${ }^{3}$ and attendance has decreased (DfE 2018b ${ }^{4}$; DfE 2018c ${ }^{5}$ ). This article considers these coinciding trends by presenting a study that explored 40 secondary-school students' perspectives of their low attendance. Findings evidence their motivation to learn but also their growing disillusionment with curriculum content that is not easily accessible or seen to support a good life, which in turn has impacted their motivation to attend school. Conclusions call for collaborations to be developed between school leaders and students to help make explicit the pathways to a good life that the curriculum claims to support. Collaborations that may also address student absenteeism.

Key words: School, Absenteeism, Students, Curriculum, Motivation, Good Life.

\footnotetext{
* Simon Edwards, BA, MA, PhD, MBE Senior Lecturer Youth Studies

** Evie Parmar, Graduate student BA (hons) Childhood and Youth Studies

1 Brynjolfsson, E. and MacAfee, A. (2014) The Second Machine Age: Work, Progress and Prosperity in a Time of Brilliant Technologies. W.W. Norton and Company.

2 DfE (2017a) Unlocking Talent, Fulfilling Potential A plan for improving social mobility through education (APS Group, HMSO).

${ }^{3}$ DfE(2018a) Statistical First Release 2018. GCSE and equivalent results in England 2017/18.

4 DfE. (2018b). Pupil absence in schools in England 2017-2018. Department for Education.

5 DfE. (2018c), Overall absence rate for state-funded primary, secondary and special schools by local authority, England - 2017/18. HMSO.
} 


\section{INTRODUCTION}

Currently in England, there is increasing political and media concern that attempts by successive governments in England to raise student attainment levels at KS1-4 ${ }^{6}$ over the last 20 years (DfEE 20017; DfE 2017a) have had little effect. Indeed, specifically and more recently, attempts to raise attainment nationally have focused on curriculum reform in line with other 'high-performing jurisdictions' (House of Commons 2014, 10) ${ }^{8}$. However, this has not been without criticism, particularly as it is now characterised by 'endless lists of spellings, facts and rules' and 'mountain[s] of data' (ibid., 10). Nonetheless, reforms since 2015 have maintained this path in order to increase perceived rigour and combat prior 'dumbing down' of the curriculum (House of Commons 2017, 6). ${ }^{9}$ Yet, despite this restructuring and partly related to changes in GCSE exam ratings, average point scores for GCSE attainment ${ }^{10}$ at the end of KS4 in schools across England have fallen in the last three years (DfE 2018a).

Coinciding with these curriculum reforms and this fall in attainment levels is a notable rise in persistent student absenteeism (DfE 2018). ${ }^{11}$ Although increasingly punitive measures have been placed on parents to ensure their children's attendance in the form of fines and threats of imprisonment in England (Criminal Justice and Courts Act 2015; DfE 2017b), ${ }^{12}$ this has had little effect. Moreover, these trends converged in a recent (August 2019) ${ }^{13}$ article

${ }^{6}(\mathrm{KS}=$ Key stage $) \mathrm{KS} 1=5-7$ years, KS2 $=7-11$ years, KS3 $=11-14$ years, KS4 = $14-16$ years.

${ }^{7}$ DfE (2001). Schools Building on Success. London: HMSO.

${ }^{8}$ House of Commons. (2014). Underachievement in education by white working class children (HC 142), (London, The Stationery Office).

${ }^{9}$ House of Commons. (2017). GCSE, AS and A level reform (England) (HC 06962), (London, The Stationary Office).

${ }^{10}$ GCSEs in England are awarded 1-9 points. Grade $\mathrm{G}=1$ point, Grade $A^{*}=8$ points (except English and maths: Grade $G=2$ points, Grade $A^{*}=9$ points). Average score is taken from the best eight subject grades.

${ }^{11}$ Department for Education (2018). Pupil absence in schools: 2017 to 2018. London.

${ }^{12}$ DfE (2017b) Guidance on Exclusions for Head Teachers Exclusion from maintained schools, academies and pupil referral units in England: Statutory guidance for those with legal responsibilities in relation to exclusion. Department for Education.

${ }_{13}$ Adams, R. (2019). Pupils receive GCSE results as concerns raised over new format. The Guardian. Available online at: https://www.theguardian.com/education/2019/aug/21/ pupils-refusing-to-sit-gcse-exams-due-to-tougher-format (accessed 23rd December 2019). 
in the Guardian newspaper that reported head teachers' and teachers' concerns about low-attaining students who were refusing to sit GCSE exams due to inaccessible content and their fear of failure. Concerns were specifically raised by head teachers and teachers about GCSE content suited to more able students at the expense of disadvantaged and vulnerable students. One teacher pointed out:

It is just focused on memorisation rather than engagement and application. There's no joy in learning any more.

(ibid., para 14)

It is within the context and confluence point of these coinciding trends that this article presents and discusses the findings from a small study commissioned by the Council X (CX) inclusion team carried out in March 2019. CX statistics were in the highest band for persistent and overall student absenteeism ${ }^{14}$ in England (DfE 2018a; 2018b) - that is, below 90\% attendance since September 2018. The most frequent levels of absenteeism were recorded, again in line with national statistics, among students in years 9 and 10. Moreover, a media campaign also commissioned by CX, which targeted parents and students by addressing their perceived low aspirations and a lack of awareness of the benefits of curricular learning for gaining a good job, was having little affect. Hence, the study explored 40 year 9 and 10 secondary school students' perspectives of their persistent absenteeism in order to evaluate and possibly redirect this media campaign.

The findings however, challenge assumptions underpinning the media campaign and evidenced the students' high aspirations and motivation to learn but also their growing disillusionment with inaccessible curriculum content that led to their increased absenteeism. It is here that divergent views on notions of the good life and the role of curriculum in pursuing this life emerge and are examined in this article.

\footnotetext{
14 Here, absenteeism means authorised (i.e. due to sickness or bereavement) and nonauthorised (i.e. due to refusing to attend school, truanting, or going on holiday without authorisation) absence but does not include fixed-term or permanent exclusions. Persistent absenteeism applies only to students who have missed $10 \%$ or more of their own possible sessions (DfE 2018a). Overall absenteeism means the total amount of sessions that a student might have missed (DfE 2018a).
} 


\section{BACKGROUND}

Education policy and curriculum reform in England, and other jurisdictions, is currently primarily driven by neo-liberal ideology that draw together a range of concepts related to marketisation, privatisation, self-identity and personal liberty (Edwards 2018). ${ }^{15}$ For example, the policy document Education Excellence Everywhere states:

Education has the power to transform lives and (. . .) is a matter of social justice-extending opportunity to every child, wherever they live and whatever their background. Good schools and a well-educated population make our country stronger, fairer, wealthier and more secure, and higher standards in the classroom mean better life chances for everyone.

$(\text { DfE 2016, 3) })^{16}$

Here, education is viewed as a means to national economic success, which is intrinsic to notions of personal liberty and social justice. Indeed, and corresponding with Webb, Gulson and Pitton's $(2013,3)^{17}$ claims, neo-liberal ideology can be summarised as one that compliments and extends the production of the self, whilst teaching practice linked to this promotes the development of autonomous and free individuals who are provided with self-regulated mechanisms with the ultimate goal to become responsible for their own care. Here, responsibility for the production and maintenance of the self and personal freedom, once the collective responsibility of the individual, their family, communities and the state is placed firmly at the feet of the individual (Bauman 2000). ${ }^{18}$

Underpinning this ideology are meritocratic notions of achievement, where an individual's academic success is seen as the reward for their effort and making the best use of tools (i.e. curriculum content and learning resources) available to them. Moreover, it is assumed each individual has the capacity to access and make use of these tools and apply them to this task (Sims-Schouten and Edwards 2016).$^{19}$ Here,

15 Edwards, S. (2018) Re-engaging young people with their education. The steps after exclusion and disengagement, (Basingstoke, Palgrave Macmillan).

16 DfE. (2016). Educational Excellence Everywhere. HM Stationary Office.

17 Webb, P., Gulson, K, and Pitton, V. (2013). "The Neo-Liberal Education Policies of Epimeleia Heautou: Caring for the Self in School Markets." Discourse: Studies in the Cultural Politics of Education 35 (1):31-44. doi:10.1080/01596306.2012.739465.

18 Bauman, Z. (2000). Liquid Modernity. Polity Press.

19 Sims-Schouten, W., and Edwards, S. (2016). "Man up!” Bullying and resilience within a neo-liberal framework. Journal of Youth Studies, 19(10): 1382-1400. 
personal freedom, citizenship, notions of fairness and social justice, from a neo-liberal ideological position are found serving the concerns (primarily the economic well-being) of the state before the concerns of family or the individual. This is seen in recent UK policy on school exclusion, which states a student may be excluded from the school for 'first seriously harming the education of peers then their welfare' (DfE 2017, 6). Note here the good of peers' education precedes the good of individual welfare in this context. Placing the economic good of the state over the good of individual well-being is further echoed in Education Excellence Everywhere, which says 'education is the hallmark of a civilised society, the engine of social justice and economic growth' (DfE 2016, 5). Curriculum content is therefore deemed to provide the necessary skills and knowledge to train students to this end (DfE 2016). Non-compliance is consequently not an option and is met with increased coercion, surveillance and punishment for the individual (exclusion and taking away of freedoms such as break times - DfE 2017) and their family (fines - Criminal Justice Act 2015). ${ }^{20}$

However, to contextualise the study and the findings that are explored in this article, it needs to be recognised that this neo-liberal ideology sits within the wider social conditions of contemporary global consumer culture, which has emerged from the processes of modernity, fuelled by the industrial revolution (Edwards 2018). Here, the disembedding of social mechanisms and structures, massification of labour and centralisation of power underpinned by successive education systems and policies in England, and other jurisdictions, has primarily placed students' intrinsic value in their worth as units of knowledge capital (Bauman 2000; Bauman and Raud 2015). ${ }^{21}$ In short, the processes of modernity have led to cultures characterised by individualism and consumerism. In terms of education policy individuals (students in this study) have become consumers (of curriculum content) and also producers (GCSE exams) of knowledge in school as an exchangeable good (i.e. accreditation/training for employment) in the marketplace. However, with the coinciding erosion of fixities of the past, such as traditional employment pathways and traditional family units, the construction of one's biographical identify in the form of creating and maintaining a viable self-narrative has become a daily task (Bauman 2000). Consequently, consumerism extends to the consumption and production of meaning as an intrinsic good. Meaning-making activities therefore include developing knowledge in lessons for the production of GCSEs that enable individuals to create and maintain this future-orientated

\footnotetext{
${ }^{20}$ Ministry of Justice. (2015). Criminal Justice and Courts Act. Circular 2015/01. Ministry of Justice, Criminal Law and Legal Policy Unit.

${ }^{21}$ Bauman, Z. \& Raud, R. (2015). Practices of Selfhood. Polity Press.
} 
(Giddens 1991)22 self-narrative. At this juncture, private life (the construction of a viable narrative) coincides with the public sphere (the construction of units of capital/economic citizens for the marketplace). Social justice, citizenship and individual freedom are therefore intrinsic and inseparable from the economic goals of the state, but are consequently held in tension between maintaining responsibility for the economic good of the nation and one's individual good (personal freedom) for which the former precedes the latter. Here, classic liberal notions of individual freedom (see Mills 1869) ${ }^{23}$ stand precariously alongside and, arguably, juxtaposed to an increasingly influential free market economy (Forrester and Garratt 2016). ${ }^{24}$

It is perhaps at this confluence point of juxtaposed pathways to personal freedom that national curriculum reforms have remained at best static and at worst in decline; and conversely absenteeism increases. There are, of course, other factors that have been found to impact student attainment. For example, perceived low student and parent aspiration (Stahl 2014), ${ }^{25}$ feeling undervalued in the classroom (Reay 2006; House of Commons 11 June 2014 HC 142) $3,{ }^{26}$ inappropriate curriculum (Demie and Lewis 2014), ${ }^{27}$ poverty and parental engagement with their child's learning (King and Welch 2012; DfE 2011). ${ }^{28}$ Moreover, factors found to impact absence include family illness and family holidays (DfE 2018a). Yet what is of concern and central to this article, is that whilst authorised (i.e. due to

\footnotetext{
22 Giddens, A. (1991). Modernity and Self-Identity. Cambridge: Polity Press.

23 Mills, J. (1869). On Liberty London: Longman, Roberts \& Green.

${ }^{24}$ Forrester, G. and Garratt, D. (2016). Education Policy Unravelled. 2nd edition. London and New York: Bloomsbury.

25 Stahl, K, D. (2014) New insights about letter learning. Research into Practice, 68(4), 261-265, Available online at: https://ila.onlinelibrary.wiley.com/doi/full/10.1002/trtr.1320 (accessed 16 October 2018).

${ }^{26}$ Reay, D. (2006). The zombie stalking English schools: Social class and educational inequality. British Journal of Educational Studies, 54(3), 288-307. Available online at: https://www.educ.cam.ac.uk/people/staff/reay/bjes-zombie.pdf (accessed 16 October 2018).

27 Demie, F. \& Lewis, K. (2014) Raising the achievement of white working class pupils, available online at: https://www.lambeth.gov.uk/rsu/sites/lambeth.gov.uk.rsu/files/Raising_t he_Achievement_of_White_Working_Class_Pupils_-_Barriers_and_School_ Strategies_2014.pdf (accessed on 13 November 2017).

28 King, L., and Welch, T. (2012). Successful white boys, of British origin, eligible for free school meals: phase 1: research and implications to date. The schools network, available online at: https://webcontent.ssatuk.co.uk/wp-content/uploads/2013/01/FSM-report.pdf (accessed 16 October 2018).
} 
illness/holiday) absences have decreased since 2007, unauthorised absences have increased (DfE 2018a).

Indeed, CX had experienced similar trends in attainment and absenteeism despite developing and promoting a media campaign that attempted to address two of these factors - aspiration and parental engagement with students' learning. The campaign themes were:

an aspirational one - titled 'What you could become' - which shows Authority $X$ pupils looking in the mirror at a representation of what their future jobs and careers could be if they go to school regularly, and a second theme called 'Your life depends on it' - aimed at secondary school pupils, which uses stronger imagery to highlight how the outcome of a student's life depends on them committing to achieving high attendance rates.

Key underlying assumptions were made here though. First, that schools in the city were offering a range of opportunities and learning experiences within and beyond lessons that could release students' educational potential and open doors to them by way of a good job and a subsequent good life. Second, that these students and their parents had low aspirations and students were not aware of, or motivated to achieve GCSEs in order to reach their potential in education. With this in mind, this study sought students' views about their low attendance in order to evaluate and possibly redirect the media campaign and direct it to address the concerns and educational needs of these students.

\section{METHODOLOGY}

Drawing on this discussion, the study located student experiences and perspectives of attendance at school within the processes of constructing and maintaining a future-orientated self-narrative (Giddens 1991; Edwards 2018; Farouk 201729). The aims were:

1. What are the educational aspirations and goals for students who have low attendance at school?

2. What are the issues and barriers that lead to these students' low attendance at school?

3. To what extent can these issues and barriers be addressed through CX's media campaign?

${ }^{29}$ Farouk, S. (2017) My life as a pupil: The autobiographical memories of adolescents excluded from school, Journal of Adolescence. Vol. 55, 16-23. 
The study was carried out with ethical approval from University of Portsmouth, CX and the head teachers at two participating schools two schools who had been invited by CX to participate in the study. The student cohort was $98 \%$ white British, and each school had an immediate catchment area in which there were relatively high levels of social deprivation.

School-based contacts (SBC) were identified by the head teachers to act as gatekeepers to their respective safeguarding and child protection policies throughout the study. The SBCs forwarded information letters and met with male and female students in years 9 and 10 to invite them to participate in the study. Students had an average attendance (since September 2018) of 70\%-90\%, including authorised and non-authorised absences but not including fixed- or short-term exclusions. Mixed groups were avoided (although one was formed by an SBC) as they may have hindered the students' responses due to power imbalances prevalent between students of different genders and age ranges. Table 1 below shows the participant profiles.

Students who agreed to participate attended a focus group with the researchers, but without the SBC present. Focus groups were favoured, as they had an advantage over in-depth interviews in that they enabled a number of people to be interviewed simultaneously. Individual responses could then be used to stimulate the responses of others. Group interviewing also meant that consensus around particular opinions or beliefs could be quickly gauged.

Following some informal ice-breaker activities that helped develop a rapport between the researchers and students, three specific lines of inquiry were explored that corresponded with a series of pictures placed in the centre of a table, around which the students and researchers were sat. The students were asked to write comments on Post-it notes then place them anonymously on each picture, which

Table 1.

\begin{tabular}{|c|c|c|c|c|c|}
\hline School & Group & Year & Gender & N & Av attendance\% \\
\hline A & 1 & 9 & M & 3 & 87.3 \\
\hline A & 2 & 10 & M & 3 & 78.5 \\
\hline A & 3 & 10 & F & 3 & 88 \\
\hline A & 4 & 9 & F & 8 & 86 \\
\hline A & 5 & $8-10$ & M/F & 7 & 80.6 \\
\hline B & 1 & 9 & M & 6 & 86.1 \\
\hline B & 2 & 9 & F & 5 & 78.4 \\
\hline B & 3 & 10 & M & 4 & 81.2 \\
\hline B & 4 & 10 & F & 1 & 87.6 \\
\hline
\end{tabular}


guided discussion about their motivations, aspirations and low attendance. Probing questions then deepened the discussion.

The pictures were i) a school; ii) the words 'Back to School'; iii) a person writing; iv) a classroom; v) the word 'Education'; vi) a signpost with the words 'Help' and 'Support'; vii) an adolescent standing next to a sign saying 'The Good Life now'; and viii) an adolescent standing next to a sign stating 'The Good Life future'.

The lines of inquiry (LOI) and corresponding pictures were:

LOI 1. The value that students placed on the concept of education and how they felt about attending school (Pictures 1-4).

LOI 2. The students' motivation to access education at their schools and the support they experienced to access education (Pictures 5-6).

LOI 3. The students' future aspirations and the role they believed education played in achieving these (Pictures 7-8).

\section{DATA PRESENTATION AND ANALYSIS}

The findings below are located under the headings of each of the three lines of inquiry.

LOI 1. Value of education and feelings about attending school

1.1. To open the discussion the students were asked to comment on Picture $1-\mathrm{a}$ school. Here, school was seen as an opportunity to socialise and learn, but a quarter of the students also said they became bored in lessons if they did not understand the content or if it was repetitive.

Arnold: I am happy with it. It's just, not like all of it, certain subjects I don't understand (. . .) probably just 'cus I don't understand it or just the subject that we're doing I find really boring.

(Year 9 group)

Tia: Some of the lessons don't even teach me nuffin. Honestly, I already know it!

Tami: The teacher does the same thing over and over again.

Kat: They don't even make it fun or different so you wanna do it.

(Year 9 group) 


\section{DOES ABSENCE MAKE THE HEART GROW FONDER?}

They were then asked: How much do you enjoy school? $(0=$ Not at all/10 $=$ A lot). Twenty-eight students responded with a mean average of $4 / 10$ and a modal average of $6 / 10$, indicating that for most of these students attending school was not highly enjoyable.

1.2. The students were then asked to comment on Pictures 2, 'Back to school', 3 , someone writing, and 4 , a teacher with a class of students. Some students said they saw school as a necessity, but, in contrast to 1.1, some also felt excited about going back to school and enjoyed most lessons.

Faith: It's like half and half. Like depending on the lessons I have. If I've got a really boring lesson like double maths I'll be like dreading to go to school but if it's something like history...

(Year 10 group)

Moreover, all of the students said they valued education as a means to gaining a good job in the future.

Ronnie: Yeah it's important cos you need a job but I'd rather do it somewhere else not here.

Tim: You need an education to get a job and success.

(Year 9 group)

Tia: It's only important because I want a good job when I'm older, that's the only reason.

(Year 9 group)

However, the value of education was contingent on it being meaningful to achieve the students' employment goals.

Tia: If I could just get a job I wouldn't even be 'ere. I wouldn't need school. That's how I actually feel - that I don't need school.

(Year 9 group)

Otis: I don't have much interest in creativity anymore. The only reason I come here is to do the work (. . .). I have two skills maths and music. Ican't get a decent career in maths at the moment so music is the best option.

(Year 10 group) 


\section{THE BUCKINGHAM JOURNAL OF EDUCATION}

1.3. Students across all of the age and gender groups also found approaches to behaviour and discipline had little impact on, or relevance to, their educational attainment. This was a source of frustration and anger that impacted their enjoyment of school

Ronnie: Like, so say like you wore trainers to school or something they just exclude ya straight away.

Lee: Who's looking at your feet during school? No one's going to look at your shoes and then take the mickey out of you. They're shoes, you're focusing on your school work!

(Year 9 group)

LOI 2. Students' motivation to access education at school and the support they received to achieve this.

2.1. The students were then asked to discuss Picture 5, which showed the word 'Education'. They were also asked: How important is education to you? $(0=$ not at all important $/ 10=$ very important). Thirty-five students responded and the mean average response was 8/10 with the modal average 10/10. Education, corresponding with 1.1, was of high importance to these students.

Moreover, the findings showed all the students were also motivated to achieve in subjects that they found enjoyable, and which were perceived to be meaningful to their lives or current youth issues.

Tia: Double English ain't that bad actually. We're normally just creative writing like so she'll put a picture on the board then we have to write about it. That's not as bad as like learning about Macbeth every single lesson (. . .). At the minute it's interesting though 'cus we're doing knife crime in English. Then we're doing a debate on Thursday.

Chloe: I've wrote loads of stories about, like, miss will say 'you have to write a story about your life' and I just write that.

(Year 9 group)

Indeed, their motivation extended to activities they found interesting beyond the curriculum content 
Kai: But I also think they should do a science fayre because I wanna do a science fayre. I wanna share about what happens if the earth goes through a worm hole.

(Year 10 group)

2.2. The students were then asked to respond to Picture 6, a signpost with the words 'Help' and 'Support' and asked: How much help and support do you get at school? Nine students said they received no help at all at school, six students said they received not much help at school and four students said they received help at home but not at school. Some students added that they were afraid to ask teachers for help because, although they wanted to work out problems independently, too much responsibility was being placed on them to make links between the teachers' explanations and their understanding of the subject content. Hence, although 1.3 and 2.1 showed they were motivated to learn, this issue demotivated them to attend school or attempt work in lessons

Joe: If you don't know something then it's your responsibility to know it but most of the time it feels like you can't ask for help (...). It's just sometimes you have to tread carefully with what you say around teachers because if you tell them too much then they could like give you a tick on your CV card or something stupid like that.

(Year 10 group)

2.3. The students were then asked specifically why their attendance was low. There were a lot of medical reasons for non-attendance, but other reasons included:

- Being bullied and this made them anxious

- Anxiety about school work

- Visiting parents who had separated

- Attending competitions (i.e. BMXing)

- Family holidays

- Family illness or bereavement

Although none of these reasons undermined the students' value of education (see 2.1), being with or supporting family members in times of difficulty or illness, or if a parent had worked away from home for a period of time and on their return needed time with their children, was of more importance to many of these students than attending school. Indeed, some students were motivated to complete work from home or to try to attend school regardless of being ill, and some students said their parents pushed them to attend school if they were ill. 


\section{THE BUCKINGHAM JOURNAL OF EDUCATION}

Faith: Yeah, I get ill quite often like when I came back from Christmas break. I had a really bad case of conjunctivitis but the school still made me come in. But my mum was like well I don't want you to spread it to anyone else (. . .). It got better cause I went to the doctors but school still moaned at me.

(Year 10 group)

However, some students said that although they valued education as being very important, they hated or were extremely anxious about attending school, which led to them becoming demotivated to attend or get in on time. This was particularly prevalent with year 9 students.

Sheldon: I hate school in general other than PE.

Joseph: I don't get up until like 5 minutes until I have to.

Ronald: If we could have Mr (xxxx) back it would be better.

(Year 9 group)

Arnold: Mines like worry about coming into school a lot cos of the lessons that I had and the teachersI didn't like either so it used to like stop me coming in.

Researcher: What made you worried?

Arnold: Not really sure, just school in general. My lessons, that I wasn't gunna understand the work, get in trouble or something.

(Year 9 group)

This anxiety had led some students to conclude that they were smart enough to get a job without the education provided at school, which had led to unauthorised their absence.

Sheldon: Yeah, because at the moment I bet you that I could just go out and get a job. Like say, work in Tesco's or somefin' like that for a couple of years. Then and actually work for my dad or something like that and learn as I go because at the moment I'm actually smarter than some of my family and they done pretty well for themselves.

(Year 9 group) 


\section{DOES ABSENCE MAKE THE HEART GROW FONDER?}

LOI 3. The students' future aspirations and the role they believed education played in achieving these.

3.1. The students then specifically discussed education in relation to their aspirations. They were shown Pictures 7, 'Good Life: (now)', and 8 'Good Life: (future)'. Specifically, they were asked to 'describe what they thought made a good life for them now and in the future'.

The findings showed that although education was valued highly by students (see also 2.1), maintaining a balance between preparing for the future and enjoying life now was difficult and had led to some students missing lessons or opting out of homework.

Millie: Not going to the lessons I don't like.

Researcher: What about outside of school?

Millie: Erm, going out with my friends, not stuck in all the time.

(Year 10 group)

Although education was widely viewed as a vehicle for achieving a good life in the future, in line with 2.4 , maintaining good relationships with family and friends was more important both now and in the future.

Ollie I'm not bothered about like, by success. I don't mean like, being rich and stuff. I just mean like, doing the best I can. Just I don't wanna just settle for nothing.

Chester: I put having friends and being happy.

Researcher: Where does education fall in there or doesn't it, necessarily?

Chester: It doesn't necessarily but it helps with making friends.

(Year 10 group)

3.2. The students then discussed their view of a good life in the future. The findings showed that this included gaining good GCSEs, but these were, in line with 1.2 , a means to becoming independent, having a family, friends and a good job or money associated with a good job. However, although it was unclear what a good job might look like, there was some evidence that it included a level of enjoyment 
and financial security, but ultimately it needed to enable students to provide for a family, i.e. a house. Here, having a house and a family was seen as a good life.

Arnold: Um, having a family and friends - a good job.

Jay: Not having to worry about, oh I've got to do this or I'm gunna get evicted or something like that (. . .). Having friends and having laughter and stuff.

Arnold: And probably making sure you've got a job you enjoy doing.

(Year 9 group)

Brian: Yeah. So I can make money buy a house and yeah, just live on my own.

Chester: I put having a good job.

(Year 10 group)

There was little difference between the responses from students across age and gender groups, although some students in year 10 wanted to gain specific GCSEs and others had some understanding of the role that college might play in gaining a specific job (e.g. architect or social worker).

3.4. Finally, the students discussed the role they thought education played in achieving their future goals. Generally, and in line with 3.1, they understood the value of education as a route to gaining a house and a job with good income but it was not always seen as the primary or most effective means of achieving this.

\section{DISCUSSION}

The opening section of this article contextualised student low attendance at two secondary schools in CX within wider political concerns about curriculum reform and ensuring economic success. Here, personal freedom, citizenship, notions of fairness and social justice, from a neo-liberal ideological position, are found primarily serving the economic well-being of the state before the concerns of family or the individual (DfE 2016). Centrally, curriculum content is deemed to provide the necessary skills and knowledge to train students to this end (DfE 2016). Moreover, teaching practice linked to the curriculum promotes the development of autonomous and free individuals who are provided with self-regulated mechanisms with the ultimate goal to become responsible for their own care. Here, responsibility for the production and maintenance of the self and personal freedom, once the collective responsibility of the individual, their family, 
communities and the state, is now placed firmly at the feet of the individual (Bauman 2000).

Yet, although the students in this study indicated a willingness to participate in lessons and attend school, the findings show that maintaining responsibility for self-regulation as a means of ensuring individual success and personal freedom was problematic. For example, the findings show these students valued education highly (see 1.3 and 2.1), but also found much of the curriculum content boring or repetitive (see 1.1). Indeed, this was a key reason that some students did not enjoy school (see 1.2) but this did not demotivate them to learn or attend lessons in which they found content meaningful to them (see 2.1). However, although also attending lessons that they did not like or for which they couldn't understand the content, the responsibility for self-regulation was becoming untenable, as Ronnie and Lee pointed out (see 1.3). This demotivated them to attend classes, and ultimately, as Tia and Otis point out (see 1.2), school in general. Moreover, although the findings also show that student attendance was, in line with wider research (see DfE 2018a), influenced by family illness, anxiety related to school or family issues and bullying (see 2.4), the findings also correspond with national statistics that show an increase in unauthorised absences (DfE 2018a) and concerns that students are refusing to attend GCSEs due to lack of understanding of content, subsequent anxiety and fear of failure (The Guardian 2019). It cannot therefore be assumed and indeed these findings raise the possibility that the students' authorised and unauthorised absences are not influenced by similar anxieties and fears.

Furthermore, the findings indicate the students were attempting to pursue personal freedom through serving the economic needs of the state (i.e. GCSE attainment and subsequent employment in a good job), but this was being restricted at least from their perspectives. Hence, they were now having to explore alternative pathways to personal freedom (see Sheldon and Tia's comments: $1.2 \& 2.3$ ). Thus, a confluence point of divergent pathways started to emerge, which were illustrated by increased teacher sanctions being met with students' refusal to attend school or lessons (3.1) and the students subsequently taking authorised and unauthorised absences that were not necessarily needed (2.3). However, the students' understanding of the value of education ought not to be misunderstood nor their aspirations seen as low, as CX media campaign had assumed, but rather their actions and absence viewed as a pursuit of a perceived good life that had necessarily taken a new pathway in response to these perceived (by students) barriers.

If these findings are to be acted upon, the underlying assumptions made by $\mathrm{CX}$ and national curriculum developers, which are underpinned by neo-liberal education policies and consequent practices need to be addressed. In the local context of CX, these might be addressed through evaluation of their media campaign in collaboration with the inclusion team leaders, students and each of 
the participating school leaders. Here, assumptions that all students have the capability to make good use of the tools provided in the classroom in order to achieve economic goals and their personal freedom (Sims-Schouten and Edwards 2016) would need to be revisited. Moreover, the further assumption that the tools are i) suitable and ii) accessible for this purpose to all students would also warrant some discussion. Particularly as the findings from this study show that, for these students at least, curriculum content was not always seen as accessible and the tools provided in the form of punitive punishments to ensure student attainment were not perceived to be fit for purpose (see 1.2, $1.3 \& 2.2$ ), consequently leading to students' demotivation to attend lessons and school (see $1.2 \&$ 3.1). Hence, absenteeism (whether authorised or non-authorised) was not simply a matter of the students' (or their parents') low aspiration, motivation or understanding of the value of education on offer as a means of achieving a good life. Rather, the findings demonstrate that the students valued education highly and were motivated to learn, but their demotivation to attend classes or school, for some of these students, was a response to lesson content that they could neither access nor see as fulfilling their potential to achieve this so-called good life.

However, the students' pursuit of the good life was not just primarily located in future economic success. Indeed, as the students pointed out in 3.1 and 3.2, a good life for them in the future included (and it seems with equal value) having friends, family, being happy and meeting theirs and their future family's basic needs (i.e. food, shelter and belonging). Consequently, their current view of a good life reflected a sense of individual fulfilment maintained in tension between i) their individual responsibilities to succeed educationally even when ill and ii) their community responsibilities to support immediate and extended family and friends when they experienced difficulties (2.3). Perhaps then, Bauman's (2000) claim that responsibility for the production and maintenance of the self and personal freedom, once the collective responsibility of the individual, their family, communities and the state, has now been placed firmly at the feet of the individual is only partly true. That is, responsibility for self-production has been placed at the feet of the individual in the context of school, but which does not necessarily (at least in the students' eyes) extend beyond the school gates. Indeed, the classroom was where these students encountered inaccessible curriculum content for which the responsibility for overcoming this issue was placed on them. Perhaps it was here that the private and public spheres coincided and consequently pathways to a good life became by necessity, divergent. This manifested itself in their increased authorised and unauthorised absences, increased punitive measures to ensure compliance, lowering of student motivation and enjoyment of subject content and students' growing disillusionment in the role of education in supporting their future goals. 


\section{CONCLUSION}

The findings from this study raise the possibility that a more fundamental issue is at play than initially assumed when exploring issues around absenteeism. That is, low student and parent aspiration, feeling undervalued in the classroom, inappropriate curriculum, lack of awareness of the benefits of education, family illness and family holidays may well be symptoms of a deeper underlying dissonance. In terms of neo-liberal market education policies, the students' knowledge is viewed as an end product - an exchangeable good for employment. Thus enabling a good life found through greater national and subsequent individual economic wellbeing. Yet, in terms of wider consumer culture students are producers and consumers, or, as Lemish $(2015)^{30}$ puts it, 'prosumers'. The tools (i.e. curriculum content and learning resources) on offer in school provide (at least for the students) more than the basis of knowledge production in terms of units of exchangeable capital (GCSEs), but opportunities to consume meaning. That is, opportunities to shape their future-orientated self-narratives that extend to their family lives now and good jobs that will support a family in the future. For the students (in this study at least), curriculum content and processes that purported to support their learning and thus bring personal meaning to this end was brought into question. Hence, to address CX and wider, national concerns about absenteeism, this underlying dissonance needs to be explored further and student voices and perspectives brought to the discussion table rather than following assumptions made about them that may lead to unproductive and costly interventions.

${ }^{30}$ Lemish, D. (2015). Children and Media: A Global Perspective. Chichester: Wiley Blackwell. 